\title{
Research on Value And Innovation Network Building for Service-oriented Manufacturing Enterprises
}

\author{
Ke Limin, Zhang Xiaoyan* \\ Alibaba Business School, Hangzhou Normal University \\ Hangzhou, China
}

\begin{abstract}
With the rapid development of technology and economy, the traditional manufacturing form is unable to adapt to the rapid development of the market. Manufacturing enterprises have gradually developed into a fusion of products and services-service-oriented manufacturing enterprises. According to the characteristics of service-oriented manufacturing enterprises, the theory of value creation is introduced to explore the connotation and characteristics of product-led logic (G-D), service-led logic (S-D), and customer-driven logic (C-D). By building a value-based network, the benefits between service-oriented manufacturing companies, suppliers and customers are maximized. Building value co-creation networks can better realize the maximization of resource utilization between each other and lay a theoretical foundation for service innovation.
\end{abstract}

Keywords-service-oriented manufacturing enterprise; value creation theory; value creation network; customer-led logic

\section{INTRODUCTION}

The demand for manufacturing companies in the current international market is shrinking, and the competition between products is becoming more and more fierce. Consumers in the market generally pursue individualization. In order to establish a foothold in the market, manufacturing companies must undergo transformation and upgrading. The needs of contemporary customers are diversified and personalized. Therefore, manufacturing enterprises must meet the needs of consumers, enhance the perceived value of customers, and form a new value-added driving force. The focus of manufacturing enterprises has gradually turned into service operations. Not the previous focus on product production. This transformation and upgrading is what we now call Service-oriented Manufacturing. Service-oriented manufacturing can bring new business models to manufacturing companies and meet the individual needs of customers.

Service-oriented manufacturing is simply a fusion of manufacturing and service industries, which blurs the boundaries between the two, allowing each other to blend more perfectly and achieve value creation.

In foreign countries, with the continuous development of the service economy, how to realize the value creation of service-oriented manufacturing enterprises, customer networks and suppliers has become a hot topic in the academic world. At the same time, more and more enterprises have begun to transform their practice. In recent years, many foreign companies have successfully transformed from traditional manufacturing enterprises to emerging service manufacturing enterprises, providing more value creation for enterprises, customers and suppliers. For example, Xerox Group (XEROX), a famous industrial company in the 20th century, is the inventor of the static film printing technology. Xerox has always been proud of this technology. But in 1975, Xerox was asked to sign a core patent license agreement with the US Federal Trade Commission (FTC). After the agreement was signed, Xerox was in an unprecedented fierce competition. But now Xerox is in a crucial transition period, from industrial manufacturing to service-oriented. Xerox now offers a new model: all copying and printing equipment is owned by Xerox and then the customer is charged for the use of these equipment Xerox calls this model "print service management"; General Electric (GE) is the global leader in aircraft engine manufacturing. However, the new engine market is a competitive market, and aircraft manufacturers are also highly concentrated, so GE It is difficult to earn too much profit by selling engines. But GE is transforming and upgrading. Now GE is the world's largest service company in the field of machine media, technology, consulting and finance. It can solve problems for consumers and propose perfect solutions.

Domestic enterprises also have successful cases, such as Shaanxi Drum Power Co., Ltd. In the early 21 st century, Shaanxi drum faced the dual pressure of shrinking market share and product line too much. The company decided to refer to foreign companies and combine their own enterprises. The transformation of its characteristics has shifted from focusing solely on the production of products to providing integrated products and services. Shaanxi drum's service strategy is closely related to its core competitive technology, and strives to make this concentric circle bigger and bigger.

However, more and more companies now have strong imitation capabilities, which has led many companies to maintain their own unique competitive advantages and core resources, and to maximize value creation. The survey found that there are two common phenomena in service-oriented manufacturing enterprises:

(1) The relationship with customers, there are many manufacturing companies that do not have a dedicated customer system, which means that they do not subdivide their own customer groups. When a company does not carefully study and analyze its own customer base, it cannot observe the changes in customer demand in a timely manner, nor can it adjust its production to the customer group in time. This will result in wasted resources and will lose some value. 
(2)The relationship with the supplier, the relationship between the manufacturing company and the supplier is very delicate. On the one hand, some suppliers, with the accumulation of business experience, hope to directly skip the direct marketing of the manufacturing enterprise and the customer, so that There will be a "springboard" phenomenon. On the other hand, some suppliers may become competitors of the enterprise, which is undoubtedly the heaviest blow to the manufacturing enterprise.

Analysis of the reasons, in the final analysis, is the value creation between service-oriented manufacturing companies, customers and suppliers. Building a value-creating network can reposition the relationship between service-oriented manufacturing companies, suppliers, and customers. Value co-creation theory can solve the problem of the distribution of benefits encountered in the development of service-oriented enterprises, and can provide new ideas and strategies for service-oriented manufacturing enterprises. This paper mainly analyzes the value of service-oriented manufacturing enterprises based on customer-led logic, and establishes a value-creation network model to provide better suggestions for service-oriented manufacturing enterprises in China.

\section{EVOLUTION OF THE SERVICE PARADIGM}

In traditional manufacturing enterprises, the company's strategy is mainly focused on the production of products. The main goal of the company is to produce high-quality products to have advantages in the market. But in the 1980s, this traditional notion was abandoned, and Vandermerwe and Rada first proposed the concept of "Servitization of Manufacturing." They believe that manufacturing companies should shift to "goods-service packages" and that services dominate the entire "package"0.

\section{A. Product Leading Logic $(G-D)$}

Product-led logic refers to the exchange of tangible products, and service is only an add-on to enhance tangible products $^{[2]}$. Throughout the theoretical research abroad, the earliest cognition of service is mainly in the classical economics theory ${ }^{[3]}$. The logic is mainly based on Adam Smith. When Adam Smith conducted a market economy inquiry, he believed that value was embedded in products and realized value through transactions, which is the exchange value of products. In the era of industrial economic development at that time, product-led logic became the mainstream idea at the time. Under the leadership of product logic, manufacturing companies are only concerned with the production of a large number of products to reduce costs, and do not pay attention to the needs of the market and customers.

\section{B. Service Leading Logic (S-D)}

With the development of society and the improvement of people's knowledge, as well as the recommendation research of marketing paradigms, people began to realize the important position of services in the market. The product-led logic that lasted for more than two centuries has been unable to adapt to the development of the market. Therefore, the service paradigm officially begins to operate, which is the service-led logic, and people no longer use products to define services.
Scholars such as Voss formally proposed research propositions for service experience ${ }^{[4]}$.

Service-led logic believes that service is the main content of exchange activities. It is not attached to products. It is the process of providing knowledge to the other party by using knowledge and skills. In the service-led logic, products still play an important role and are the carrier of services. In the fierce competition in the market, products are easily replaced by imitation, so the competitiveness of products is gradually declining, and services are not easily replaced by imitation, and services have gradually become the competitive advantage of manufacturing enterprises. More and more manufacturing companies are beginning to realize the importance of product service, and service has become a key factor in manufacturing companies to stimulate the market. Service-led logic Zhuangjiazhuang focuses on the dynamic relationship between producers, suppliers and customers, and pays more attention to building value interaction. Under the service-led logic, manufacturing companies no longer consider their own interests, but also consider the interests of suppliers and customers. Under the service-led logic, manufacturing companies began to expand the company's services, making the company's services a competitive advantage in the market.

\section{Customer Leading Logic (C-D)}

With the deepening of research, some scholars have begun to realize that customers are at the core of building value networks. Service-oriented manufacturing companies are starting to think about what products they really want from the perspective of customers, rather than thinking about my production. What products and services can bring to consumers Consumers are not only economic people, but also social people, and have close ties with society. Manufacturing companies want to maximize their value network and need to put customers at the core, so customer-led logic emerges.

The customer-led logic only refers to the enterprise that takes the consumer's needs and experiences as the core, and designs the products and services around the consumers. The service-oriented manufacturing enterprises are the participants of the activities, and are not the initiators of the value-creation activities $^{[5]}$. This logic is very different from the former two. This logic requires manufacturing companies to have a long-term perspective to tap the needs of customers, and then companies must fully meet the needs of consumers. Under the customer-led logic, consumers are fully committed to value-creating activities, and all activities of manufacturing companies are centered around the customer. Unlike service-led logic, services at this time are embedded in everything from the customer experience. All services are designed to give customers a better sense of experience and use.

With the continuous research and development of theory and practice, service economy has different development paradigms in manufacturing enterprises, and each stage has its existence value. A summary control according to the above is shown in Table 1. 
TABLE I COMPARISON OF DIFFERENT LOGICAL EVOLUTIONS

\begin{tabular}{lllll}
\hline & G-D Logic & S-D Logic & C-D Logic \\
\hline Main object & product & service & $\begin{array}{l}\text { Consumer practice } \\
\text { and experience }\end{array}$ \\
\hline $\begin{array}{l}\text { Active } \\
\text { subject }\end{array}$ & enterprise & enterprise & consumer & \\
\hline $\begin{array}{l}\text { Value } \\
\text { embodiment }\end{array}$ & exchange value & use value & $\begin{array}{l}\text { use and perceived } \\
\text { value }\end{array}$ & \\
\hline $\begin{array}{l}\text { The cluster } \\
\text { form }\end{array}$ & supply chain & $\begin{array}{l}\text { value } \\
\text { extension }\end{array}$ & $\begin{array}{l}\text { chain } \\
\text { value }\end{array}$ & creation \\
\hline
\end{tabular}

III. CUSTOMER-LED LOGIC TO EXPLORE THE VALUE CREATION ACTIVITIES OF SERVICE-ORIENTED MANUFACTURING ENTERPRISES

From the perspective of customer-driven logic, the realization of value co-creation is inseparable from the interaction between service-oriented enterprises and customers. For service-oriented manufacturing companies, value creation is to enter customers into most aspects of the enterprise. Participate in the participation of customers in the development, design and after-sales of some products. Although products and services are developed by service-oriented manufacturing companies, there is a unique sense of customer experience under the customer-led logic. The realization of value co-creation needs to give full play to the role of customers and realize the interaction and integration between enterprises and customers. The value creation theory model under customer-driven logic is shown in Figure 1.

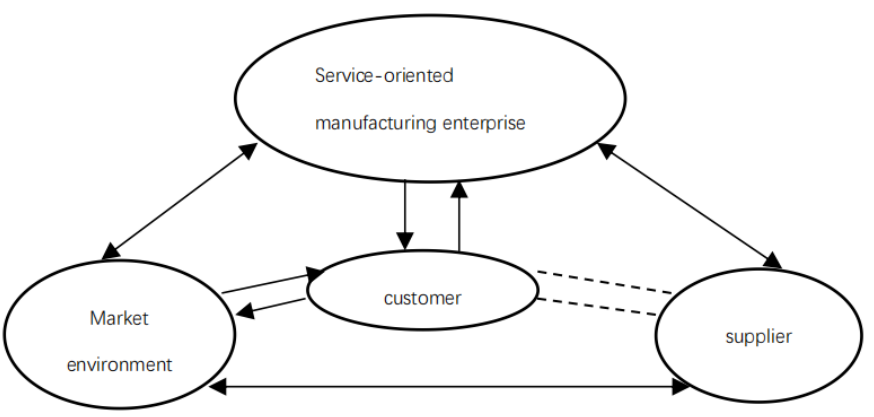

Fig. 1 The value creation theory model under the customer-led logic

Service-oriented manufacturing companies need to maintain a good interaction with customers is the key to building value to create a network. In the value co-creation network, the information between the parties is shared, so that the value between the parties can be fully utilized. Under the customer-led logic, the relationship between service-oriented manufacturing companies, suppliers, customers and the market is also closer. In the value co-creation network, if the relationship is not close enough, it may lead to the loss of the network. Only when the relationship is close can we develop products that are suitable for the market and satisfy consumers, so that there will be no overcapacity for service-oriented manufacturing companies. With the addition of customers, for service-oriented manufacturing companies, they can expand their product chain, generate economies of scale, and promote the growth of economic benefits.

Under the customer-led logic, the construction of the value network pays more attention to the relationship between the service-oriented manufacturing enterprise and the customer. The two are interdependent and mutually influential. By understanding the needs of customers and communicating with customers, service-oriented manufacturing companies can realize the exchange and utilization of resources. Through participation, customers can produce products that are more in line with their own needs. In the value creation network, customers not only provide value to service-oriented manufacturing enterprises, but also create value for themselves and enhance their use value ${ }^{[6]}$. Under the customer-led logic, service-oriented manufacturing companies communicate and cooperate with customers, fully combine their resources, break the internal and external constraints, and achieve value creation. As shown in Figure 2.

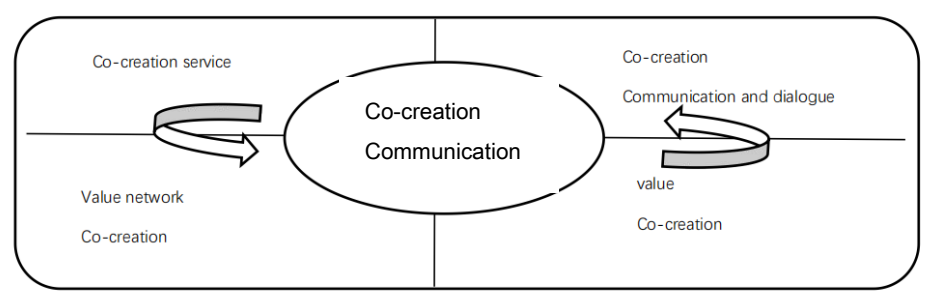

Fig. 2 Relationship between service-oriented manufacturing enterprises and customers in the value creation network

\section{SERVICE-ORIENTED MANUFACTURING SYSTEM UNDER THE VALUE CREATION MODE}

From the perspective of value creation, the dynamic link between service-oriented manufacturing companies and customers makes the production process and consumption process more optimized, and then realizes value creation. In the value co-creation network, customers and service-oriented enterprises are no longer two separate systems, but the two are mutually infiltrated. Service-oriented manufacturing companies collect and analyze customer needs, and create value together with customers; customers truly enter the enterprise, no longer isolated and co-production with the company. Under the value-creation model, service-oriented manufacturing companies and customers integrate with each other to form a new system. As shown in Figure 3. 


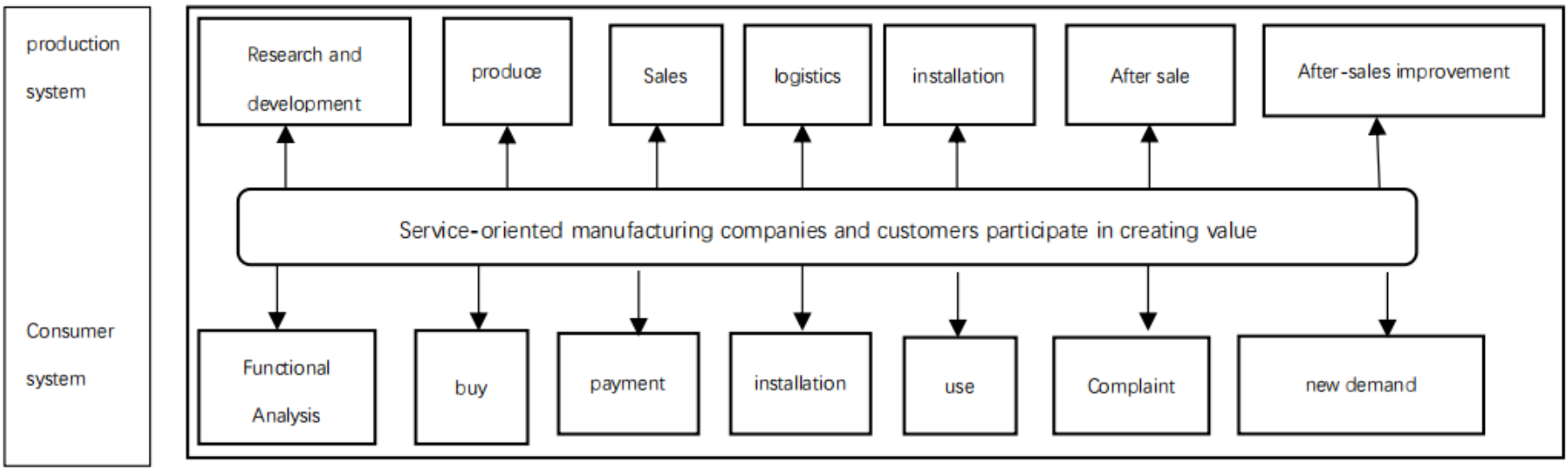

Fig. 3 Service-oriented manufacturing system in value-creation mode

Service-oriented manufacturing enterprises under the value-creation model not only have production and service links, but also integrate logistics and information flow. Service-oriented manufacturing enterprises under the value-creation model have the following characteristics:

(1)In the operation mode, in the value creation network, service-oriented manufacturing enterprises are no longer just product-centric, but turn the business philosophy to the customer-centered. Actively add customers to the activities of the company, communicate with customers in a timely manner, can directly understand the needs of customers, and not operate at the enterprise itself.

(2)In value creation, service-oriented manufacturing enterprises no longer only create profits for themselves, but comprehensively measure the value of all parties, so that all parties are closely united to create value and enhance their respective values.

\section{SUMMARY AND RESEARCH OUTLOOK}

For manufacturing companies, the transition to service-oriented is undoubtedly a global trend, and it is also in line with the development of the times. Only by listening to the needs of customers and combining these needs with production can manufacturing companies gain more room for development. With the development of information, value creation theory can better provide new management strategies for service-oriented manufacturing enterprises. The current market is not a big one. If you want to go further, you must absorb the value of suppliers and customers into the business of the company. In the value-creation network, each part is no longer independent, and each other is closely connected, so that resources can be better utilized and fully reach the maximum value. Under the customer-led logic, enterprises should further analyze and mine customers and subdivide the customer groups, which is conducive to the development of theory and practice. Future research introduces more reference factors, such as incorporating other aspects of the company's management strategy and value distribution. For service-oriented manufacturing enterprises, the introduction of customers from production to design, sales, and after-sales will be more conducive to the long-term development of the enterprise.

\section{REFERENCES}

[1] He yuanqiong. Tian zhilong. Service Strategy of Manufacturers in Western Countries and their Implications to China[J]. Science \& Technology Progress and Policy,2011.(In Chinese)

[2] THARA,T,ARAI. Encourage non-designer's: continuous value creation in manufacturing products and service[J].CIRP Annals-Manufacturing Technology,2012,61:171-174.

[3] MARSHALL A. Principles Economics[M.London:Macmillan,1927:151-167.

[4] VOSS C, ROTH A V, CHASE R B.Experience, Service Operations Strategy, and Service as Destination: Foundations and Exploratory Investigation[J].Production and Operations Management,2008,17(3):247-266.

[5] KRISTINA HEINONEN, TORE STRANDVIK,PAIVIVOIMA. Customer dominant value formation in service[J].European Business Review,2013,2(25):104-123.

[6] Yu Xiaozhe. Xie qun. Research on enterprise innovation driving force based on service leading logic[J]. Modern Management Science,2019. (In Chinese) 